This is an earlier version of the article just before being accepted for publication.

Hürol,Yonca; Wilkinson, Nicholas, (2005) "A Critique of Earthquake Policies of Northern Cyprus." Proceedings of the Institution of Civil Engineering-Structure and Buildings. 158(6) pp.355-369.

\title{
A CRITIQUE OF THE EARTHQUAKE POLICIES IN NORTHERN CYPRUS
}

Yonca Hurol, Nicholas Wilkinson

\begin{abstract}
The same building codes and specifications have been used in Turkey and Northern Cyprus for more than thirty years. Similarly, the most preferred technologies are the same in both countries. One of the most frequently used building technologies is that of the reinforced concrete frame system with nonload bearing brick walls. However, when earthquakes occur in Turkey, this system frequently causes serious structural problems, culminating in building collapse and a huge loss of human life. Building codes, including those of Turkey and Northern Cyprus, usually include solutions to these problems, which can only be carried out by structural engineers, but which ignore the existence of other possible solutions, which may also be carried out by architects.
\end{abstract}

The research objective of this paper is:

1. To carry out a preliminary investigation into the existence of the same or similar problems in Northern Cyprus, but not in the southern part of the island.

2. To identfy and propose a more appropriate strategy to combat and resolve the problem. Similar research and strategies will be very important for the country in the process of unification with the European Union. For this purpose, only the "soft storey" and "short column" problems are studied as cases demonstrating evidence of the severity of the problem. With the help of a comparative research carried out in the town of Famagusta, in Northern Cyprus, the paper defines the problems, outlines the solutions to them, and compares these solutions with those defined in the building codes and specifications of other nation states. 
Ultimately, it is shown that:

- It is worth carrying out a more detailed research into the degree of the earthquake resistance of the reinforced concrete buildings in Northern Cyprus.

- It is better to propose multiplicity of solutions which will connect all the related professions in the common aim of developing a social strategy, which will combat earthquakes, if it is understood that a singular hypothesis is not in any way sufficient or adequate to solve the problem as it currently exists in Turkey to-day.

\section{A CRITIQUE OF THE EARTHQUAKE POLICIES IN NORTHERN CYPRUS}

\section{INTRODUCTION}

Many countries' building codes and specifications propose that the earthquake problem in their countries can only be solved by applying a structural engineering solution. This is also applicable to the building codes and specifications in Turkey and Northern Cyprus. Because of this, architects in both countries are not educated about earthquake problems, and they are not expected to design earthquake resistant buildings. As a result of this lack of knowledge and the lack of adherence to the building codes, those reinforced concrete buildings, which are over three storeys high, started to react very badly to earthquake activity in Turkey. However, nothing has been done to improve or alter this situation. Laying all responsibility at the door of the structural engineers is only one hypothetical world view, and single solutions can only be accepted if the problem is not complicated. However, the earthquake problem in Turkey is severe and is the cause of numerous deaths. Complex and disastrous problems, such as those in Turkey, demand the inclusion of all related professions within a social strategy which is able to provide multiple solutions. Since Northern Cyprus shares the same building code, similar technologies and economic conditions with Turkey, the same problems probably also exist in Northern Cyprus. 
The first research objective of this paper is to examine and identify the existence of a similar earthquake problem in Northern Cyprus. The southern part of the island is obviously not included in this paper. The second research objective is to propose an appropriate strategy which must be considered during the process of unification with the European Union. Eurocode-8 (EN1998) will affect the existing and future architecture of Northern Cyprus because of the life-safety objective, deformation limits to minimize the damage, and the need for retrofitting the vulnerable existing structures. (ECS, 2000; Lubkowski, Duan, 2001; Anon, 2003)

Since "earthquake resistant design" is too extensive a subject area to be addressed in one paper only the "soft storey" and "short column" problems, which occur due to problems related to the lateral stiffness of structures, are analysed as sample cases in this paper.

\section{Severity of the Problem in Turkey and Northern Cyprus}

According to Davis (1978), ninety-five percent of deaths, which occur as a result of disasters, take place in developing countries, such as Turkey. The economies of different countries affects their building code philosophies and the technological preferences of their people, depending on the cost. An observer of the damages sustained by the 1999 Kocaeli earthquake, which had a magnitude of 7.4, and the 1999 Taiwan earthquake, which had a magnitude of 7.6, compares the situation of the failed buildings in Taiwan with those in Western Anatolia: 'Yet in all the devastation and as an affected region, these buildings appear better built than those in Western Turkey where the earthquake on August 17 killed over 15000 people and injured some 47000 others. '(Seismo-watch,n.d.)

On the other hand, Northern Cyprus has not suffered any serious earthquakes for more than sixty years. According to the Cyprus Civil Engineering and Architects Association (1992), which is in the southern part of Cyprus, and Ö.Can (1997), the south-east of the island (especially Paphos) is in a dangerous earthquake zone. Buildings in this zone are safe because of careful and conservative construction. The danger decreases towards the northern and eastern parts of the island. However, the seismic hazard map of Northern Cyprus is not yet conclusive. 
According to Ergünay and Yurdatapan (1973), and the Northern Cyprus Civil Defence Organisation, Famagusta is the only city in Northern Cyprus, which is in a hazardous zone. The danger is less in the other cities or towns e.g. Nicosia, Kyrenia. The significant earthquakes occurring over of the last fifty years in Cyprus are as follows:

- 20th of January 1941 - Famagusta - Magnitude: 5.9 - 24 people died.

- 10 th of September 1953 - Paphos - Magnitude: 6.1 - 40 people died.

- 23rd of February 1995 - Paphos and Lefke - Magnitude: 5.7 - 2 people died.

- 9th of October 1996 - in the sea and around Paphos - Magnitude: 6.8 nobody died. (brochure of Northern Cyprus Turkish Republic Civil Defense Organization)

The preferred structural systems, materials and the building codes, which are followed during the design and construction of new buildings in Northern Cyprus, are similar to those in Turkey, which exhibit serious problems during all significant earthquakes. Özbilen (2004) agrees that there are also serious problems in the construction of reinforced concrete buildings in Northern Cyprus. The use of unqualified workers, the lack of site control and investigation and overview, the lack of experienced and responsible professionals, and the modifications, which are made to the project throughout the construction phase, without consulting and informing the professionals, are the reasons for this situation arising. Eurocode- 8 does not permit such modifications. (ECS, 2000)

Because of the global differences in the preferences of people concerning materials and structural systems, there are different reasons for building failure in different countries. For example, reasons for failure in Iran following the last earthquake were because of problems with the brick masonry construction. In Taiwan and China, failure occured because of problems linked to the use of mud domes and traditional light timber frames. (Hu,Liu,Dong, 1996) Similarly, the reasons for buildings failure as a result of earthquakes in San Francisco and Turkey also differ. (NCREE, n.d.; EERI, 2002; San Francisco Cronicle,n.d.) However, similarities may occur between the problems in Turkey and Northern Cyprus in the future, because of the use of similar applications. 
Between 1949 and 1969, the number of deaths in Turkey as a result of earthquakes was the second highest in the world, after China. It is known that the situation in China is now very much improved as a result of the technical cooperation, the increased and shared knowledge and support between all relevant sections of society, and all related professions (Hu, Liu, Dong, 1996). The knowledge gained from the experiences of building failure following an earthquake, is usually analysed and utilised for the improvement of the structure of buildings in many countries. This is not the case, however, in Turkey.

Reinforced concrete frames, with non-load bearing brick walls is one of the most popular building technologies in Turkey together with the masonry structures. It has also been the most popular technology in Northern Cyprus over the course of the last thirty years. The buildings in Turkey, which have reinforced concrete frame systems, sustained more damage than those buildings which use different structural systems. Both the 1992 Erzincan earthquake, which had a magnitude of 6.8, and the 1996 Dinar earthquake, which had a magnitude of 6.0, caused more damage to those buildings, which had reinforced concrete frames. In Erzincan the percentage of collapsed or heavily damaged buildings according to their structural systems were as follows: (Şengezer, 1999)

1. $5 \%$ of buildings with brick masonry structures (most probably including the ones with horizontal lintels, and those with horizontal and vertical reinforced concrete lintels),

2. $35 \%$ of buildings with reinforced concrete structures,

$3.42 \%$ of three storey buildings with reinforced concrete structures,

4. $54 \%$ of six storey buildings with reinforced concrete structures.

The resistance of this type of system is much lower in Turkey than it is in other countries. This is verified by research, which is based on similarities between characteristics (such as magnitude, distance from the centre, ...) of the 1992 Erzincan (in Turkey with a magnitude of 6.8), the 1995 Hanshin (in Japan with a magnitude of 7.0), and the 1995 Northridge (in USA with a magnitude of 6.7) earthquakes. The earthquake performance of the buildings with reinforced concrete frame structures in Turkey is four times lower than those in Japan, according to those comparisons made between the building failures of the 
Erzincan and the Hanshin earthquakes. It is also twelve times lower than the performance of similar structures in the USA, according to the comparison made between the failures of the Erzincan earthquake and the Northridge earthquake. (Erdik, Avc1, 1999)

It is anticipated that more than half of the reinforced concrete buildings in Turkey will be heavily damaged during the next strong earthquake, and this could also be the case in Northern Cyprus. According to a model of prediction of damage, which was prepared in 1995, there are 700, 000 reinforced concrete buildings above three storeys high in Istanbul, Turkey. If there is a significant earthquake (such as the 1999 Kocaeli earthquake) in Istanbul, 70, 000 of these will collapse, 200, 000 will be heavily damaged, and 450, 000 will be damaged. (Şengezer, 1999) It is clear that there is something very amiss with this popular building technology, and the earthquake policy of the country. The earthquake performance of reinforced concrete frames with non-load bearing brick infill walls, which are used for apartment housing and office buildings in Turkey, is very poor. The earthquake policy of Turkey, the political constraints in relation to the application of the policy, and the way in which it is monitored, are equally weak.

Excluding the major substructure problem caused by the soft-ground conditions, the general reasons for the failure of the reinforced concrete frame superstructures are listed in international earthquake literature as follows: (Ambrose, Vergun, 1985; Ambrose, Vergun, 1999; Key, 1988; Hu, Liu, Dong, 1996; Dowrick, 1990)

1. Problems due to building form and mass; irregularity of the structure,

2. Problems pertaining to the continuity of joints and reinforcement,

3. Problems linked to the proximity of adjacent buildings,

4. Need for shear walls,

5. Resonance, on account of the proximity of the fundamental periods of soil and the building structure,

6. Damage due to non-structural parts such as infill walls, mechanical equipment etc.. 
According to the report compiled by Istanbul Technical University (İTÜ, 1999) on the damage caused by the recent Kocaeli earthquake, the hierarchy of the reasons for the failure of the superstructure of those buildings with reinforced concrete frames are as follows:

1. Irregularity of the structure, including the existence of beams supported by beams and problems related to building form and mass,

2. Insufficient shear reinforcement at the joints,

3. Use of bad quality concrete arising from, e.g. the use of sea water to produce concrete,

4. Soft storey and short column problems,

5. Collapse of the walls which contained heat insulation layers,

6. Insufficient distance between two adjacent high-rise buildings.

If these two groups of reasons for low earthquake resistance, i.e. the one which is prepared for the world and the one which is prepared for Turkey, are compared with each other, it can be deduced that the difference in failure rate in Turkey is due to careless production, as well as a lack of knowledge concerning the significance of "irregularity of structure", "soft storey" and "short column" formations, which usually occur because of the poor design of non-load bearing infill walls. The wrong use of non-load bearing infill walls causes a negative interaction between the structure and the non-load bearing members.

\section{Building Codes and Specifications in Turkey and Other Countries.}

The 1975 building code was upgraded in Turkey in 1997 following the Dinar earthquake. The current building code is the only solution that has been developed by the Turkish government in order to solve the earthquake problem of the buildings with reinforced concrete frame systems. Both the new and the old codes left the total responsibility of solving the earthquake problems in buildings solely with the structural engineers. It is expected that the structural engineers will develop solutions such as increasing the sizes of columns and adding more reinforcement, if the architectural design of the new building creates earthquake resistance problems. However, it is a known fact that contractors and/or other responsible people do not adhere to any of these codes, and/or engineering projects. The 1939 Erzincan, 1983 Erzurum, 1992 Erzincan, 1996 Dinar, 1998 
Adana and 1999 Kocaeli earthquakes have still not enforced those people involved in the building trade, and specifically the contractors, to adhere even to the existing building codes and earthquake specifications. It seems that it is not possible for the country to monitor this problem. (Kubin, n.d.1)

It can be stated that the current building code and specifications ignore the fact that earthquake resistant architectural design would contribute greatly to the solution of this severe social problem. When the role given to architects is considered, the building codes and the specifications of many other countries are similar to those of the Turkish and Northern Cyprus building codes and specifications. However, the severity of the earthquake problem is greatly reduced in many of these countries, whereas this is not the case in Turkey. On the other hand, the building codes of Mexico City, Japan, Israel and Romania give the responsibility to architects as well as structural engineers. Eurocode- 8 also affects architectural design in that it gives consideration to the effects of infill walls on structural behaviour, and by limiting deformation in a different manner from other building codes. (ECS, 2000; Lubkovski, Duan, 2001) These responsibilities of architects can be realized during the architectural design of the building structure, or in the architectural design of the application project. (Paz, 1994) These responsibilities will be mentioned within the related sections of this text.

\section{Research Objective, Research Significance and Method}

The research objective and research significance of this paper is:

- to question the earthquake danger in respect of reinforced concrete buildings in Northern Cyprus by using the data provided by the Turkish experiences.

- to demonstrate that there are problems in the Turkish and Northern Cyprus earthquake policies by showing that the precautions that are proposed in building codes and specifications in order to reduce the impact of earthquakes are one dimensional, although the problem is still multi-dimensional, complex and severe. Instead of calling on and demanding that all related professions within the country work together to combat earthquakes, this responsibility continues to rest solely with the structural engineers. However, architectural design solutions to these problems are also possible. 
- This paper shows that the origin of many "soft storey" and "short column" problems is a result of architectural design, and that these problems, therefore, can easily be eliminated during the architectural design process.

- Furthermore, these proposed solutions are compared with the solutions proposed in the building codes and specifications of different nation states.

In order to show the relationship between these problems and architectural design, a comparative research study between a commercial and a residential street in the town of Famagusta in Northern Cyprus (Figure 1 and 2), has been prepared. This research demonstrates how frequently the problems of "soft storey" and "short column" occur, the relationship of each problem with the architectural design, and the most appropriate solution for each case, by considering the economic status of the owner. Only those buildings, less than 30 years old, are studied in both streets. Given this information, the buildings under examination were constructed solely by the citizens of Northern Cyprus, but not by the people in the southern part of the island. All the buildings have at least three levels including the ground floor level. They all have reinforced concrete frame structures with non-load bearing brick walls.

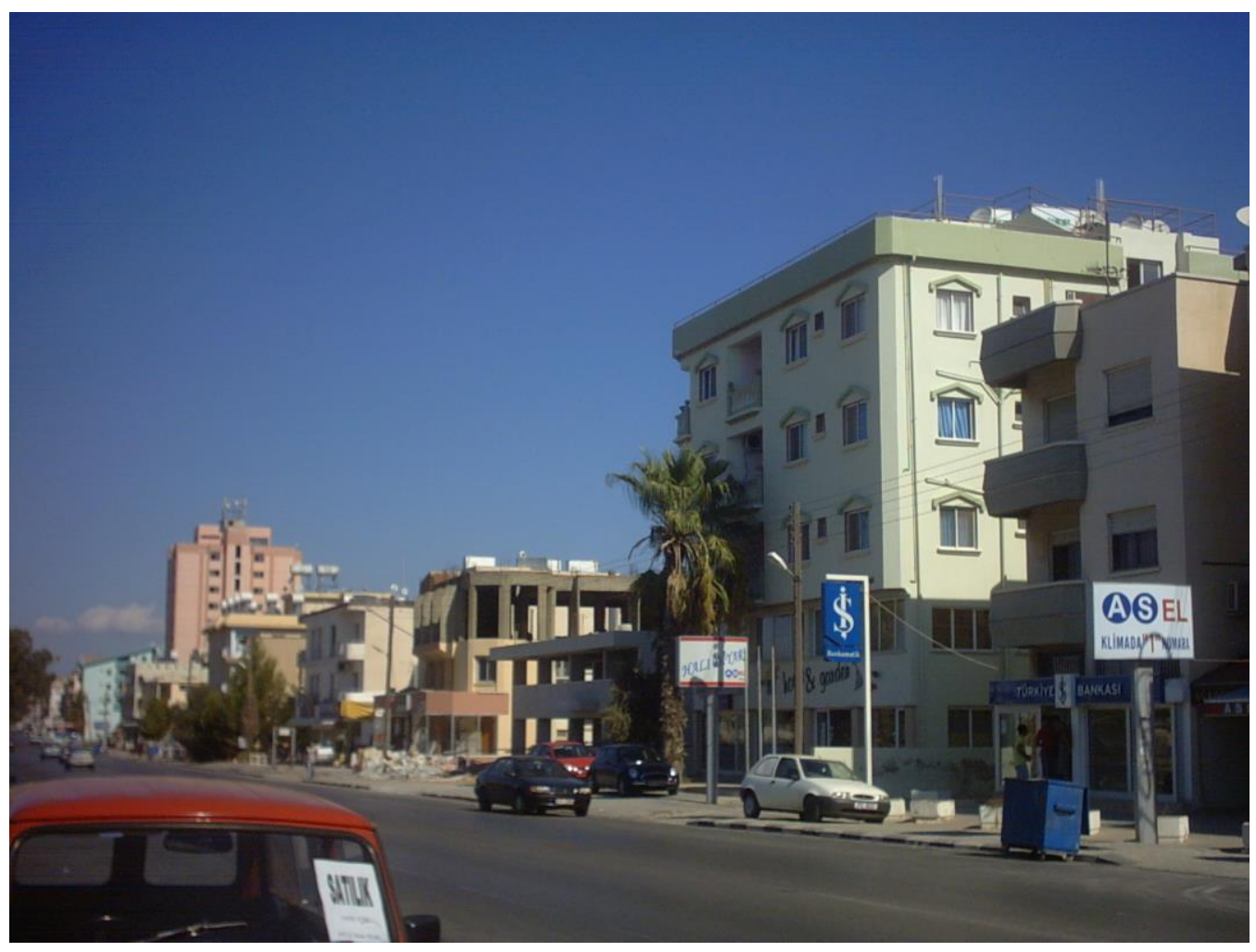

Figure 1. The commercial street in Famagusta: Salamis Road (Photo: by authors) 


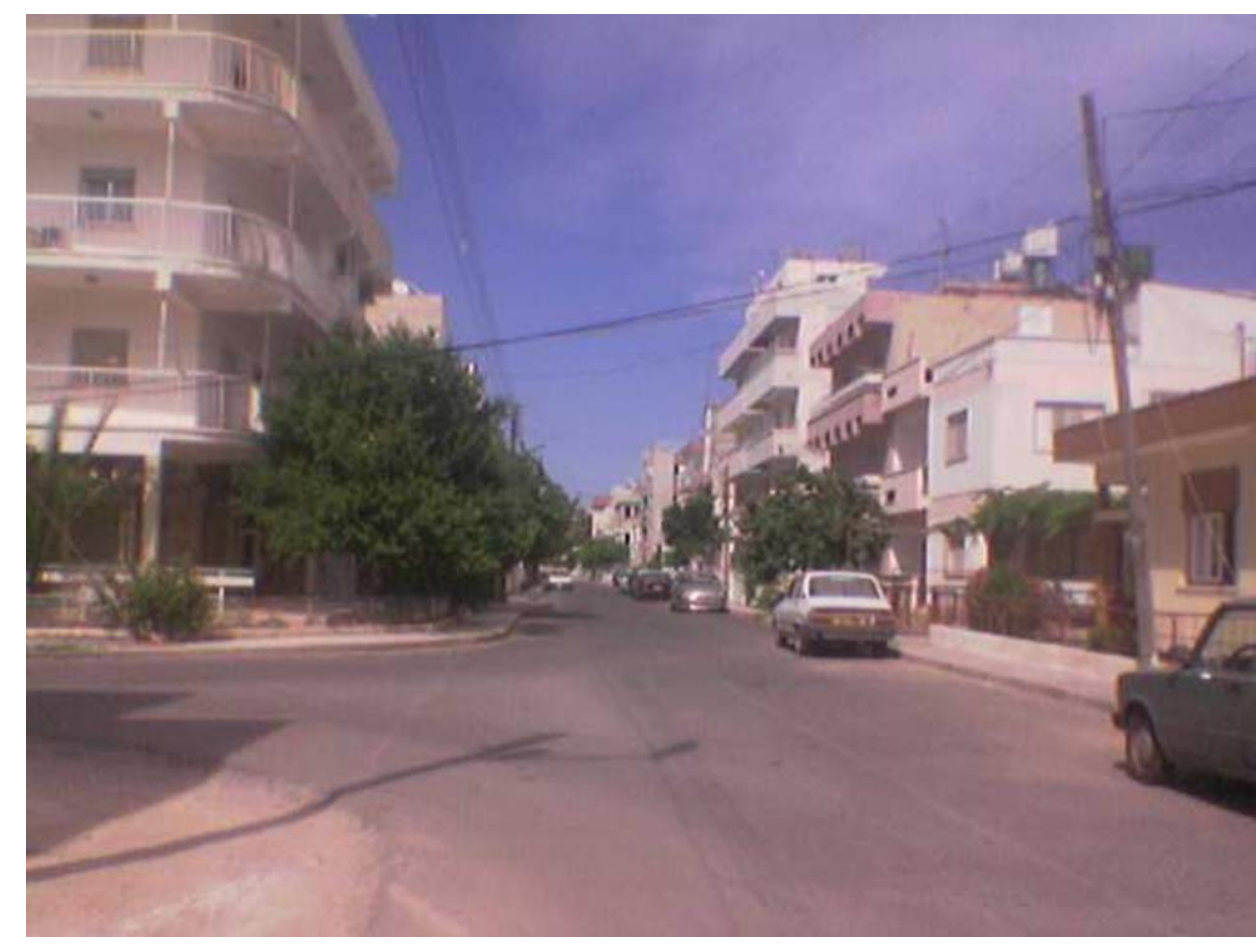

Figure 2. The residential street in Famagusta: 19th of May Street (Photo: by authors)

There are two basic methods of collecting information about the earthquake problems of existing buildings. These are:

a. The rapid evaluation method, which is based on the identification of critical structural weaknesses. This approach includes a simple building grading scheme, the preparation of detailed procedures to evaluate the condition of the existing buildings, and the cost-benefit analysis of mitigation measures. (Earthquake Engineering New Zealand, n.d.) This method is usually eployed following earthquakes in order to determine the damage, and to identify "safe" buildings for public use.

b. Placing instruments in structures to see how the structures respond during earthquakes. Every time an earthquake occurs, these instruments provide data about that structure for analysis by the structural engineers. (USGS, n.d.) This method is usually used, if possible, before earthquakes, and in order to improve the condition of the existing buildings.

In this paper, the first method is used to carry out a preliminary research into the existence of "soft storey" and "short column" problems in Famagusta, which has a population of 30,000 people. The aims of this research is to make a preliminary 
estimate of the extent of this problem, in order to realize the first step of a more detailed research, which will be based on factually, accurate information, and to determine how important the inclusion of, and the consideration given to architectural design is, in terms of avoiding and dealing with "soft storey" and "short column" problems. Thus, the problem buildings in these two streets are identified by using the observation method rather than by any other method, which would depend on measurement and/or mathemathical certainty. There are two reasons for this approach: Firstly, there is no reliable documentation on the majority of these buildings. Secondly, it is necessary to identify only those buildings, which are considered to be a possible danger, as opposed to making any actual structural engineering decisions about them.

During the observation of the buildings the following questions were posed:

1. Is there any visual evidence, which might indicate a "soft storey" and/or "short column" problem?

2. What is the architectural function of the problem area in the building?

3. What is the most appropriate way of eliminating the existing problem, in terms of the economic status of the owner?

It is preferable to effect the last step of the research in conjunction with the participation of the owner of the problem area or building. However, in this research such decisions are made according to the function of the problem area in the building, because the function (such as residential, business or commercial) can be accepted as indicative of the economic status of the owner. Consequently, the solutions, which require the use of advanced technology and/or further architectural-interior design activity, are prefered, if the problem area exists in a commercial space, because these type of solutions are the only economically viable ones for such activities. On the other hand, in residential areas, those solutions, such as maintenance, repair activities or the like, are preferable. 


\section{DEFINITION OF THE PROBLEM: "SOFT STOREY" AND "SHORT COLUMN" FORMATIONS}

The negative effects of non-load bearing infill walls on reinforced concrete frames can be analyzed under the headings of "soft storey" and "short column" problems. Ambrose and Vergun (1999) define the "soft storey" problem thus: "In $a$ multistorey structure, a storey level whose lateral stiffness is significantly less than that of storeys above it......an abrupt change in total storey stiffness between adjacent levels, between different vertical levels "' (Figure 3)

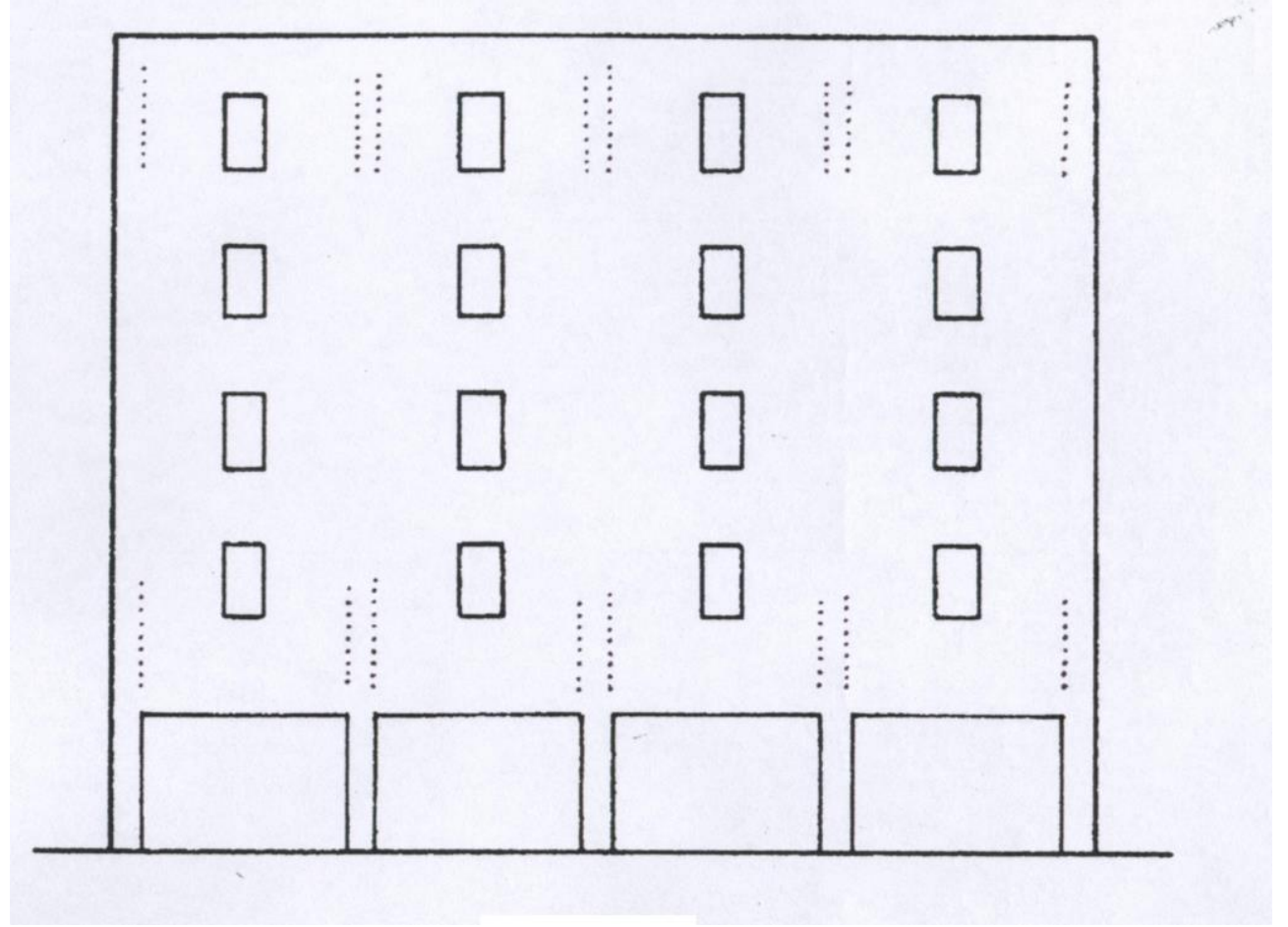

Figure 3. Graphical expression of the soft storey problem

Walls do not permit the upper storey columns to deflect. The rigid upper parts sway in the direction of the lateral load and cause the slender ground floor columns to receive an unpredicted excessive moment. This moment in the columns causes the collapse of the ground floor. 'In principle it is advantageous to isolate a structure from excessive ground movements by some sort of spongy layer. It has been proposed that a basically stiff structure could be protected from short-period vibrations by making the bottom storey columns relatively flexible. Unfortunately, many modern buildings of this type have not performed well in 
earthquakes. Studies have shown the soft storey concept to have theoretical as well as practical problems.' (Dowrick, 1990; see Dolsek, Fajfar, 2001 for further information)

The architectural idea of having the building on top of columns, is known as "pilotis," which started to be very popular together with the modern architecture of the 1920's. Although the pioneer architects of the 1920's, such as Le Corbusier, provided solutions to combat soft storey problem, his followers did not.

Key (1998) gives examples of "short column" and mentions that "the constraining effect of masonry abutting the column makes it liable to fail in shear before it fails in bending; at the weak point opposite to the window opening..." (Figure 4)

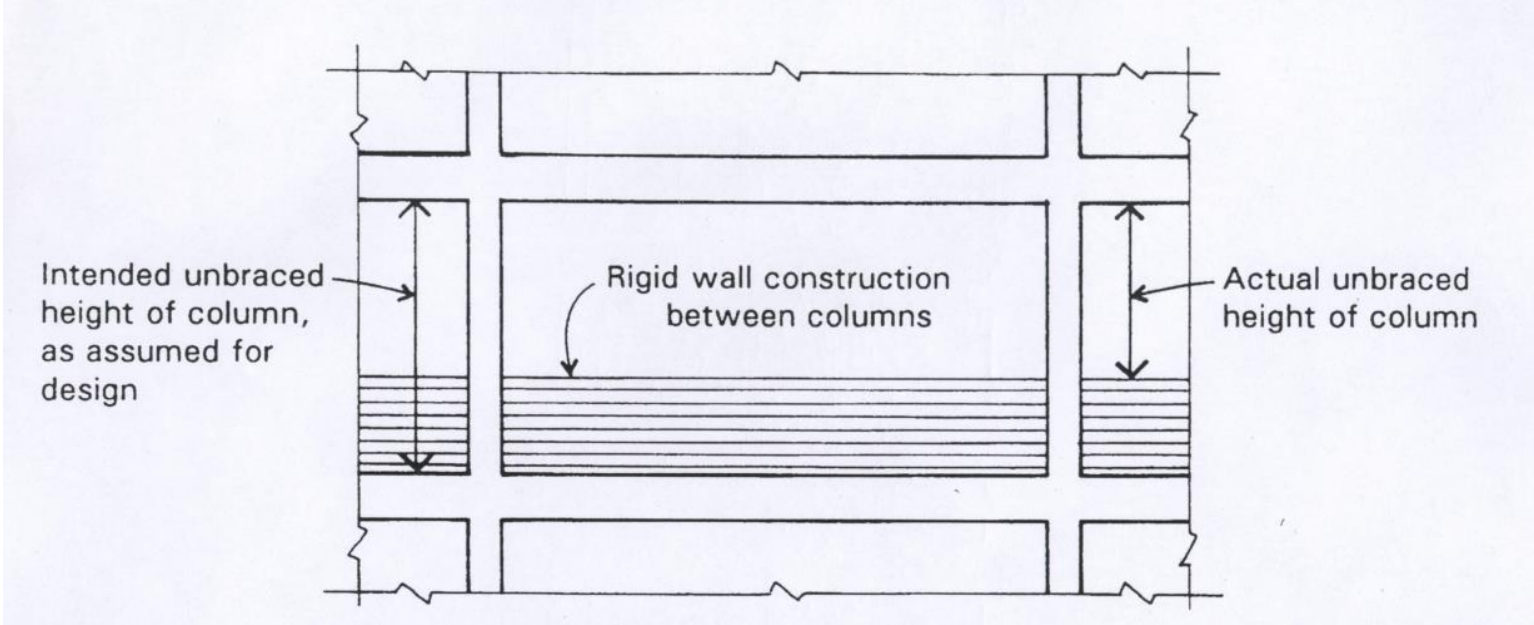

Figure 4. Graphical expression of the short column problem

The movement of the top part of the column is not restricted by the wall. However, the lower part is. The column can only bend through the height of the window. The whole shear is concentrated on that short length, and the amount of shear is increased. (Ministry of Public Works and Settlement, 1997) The increased level is unpredictable and the column collapses from shear instead of bending.

Unlike the soft storey problem, the short column problem does not occur only as a result of the negative effects of non-load bearing infill walls, but also on account of a poorly conceived structural member layout and connection of the structural 
members. Such problems usually occur in the vicinity of stairways, and areas of differing levels.

The architectural idea of having "strip windows" also became very popular together with the modern architecture of the 1920's. Again Le Corbusier, provided solutions to combat the short column problem as well as the soft storey problem, but his followers did not.

"Soft storey" and "short column" problems in Turkey, are also a result of the false assumption of architects; that only the structural systems of the buildings provide all the resistance against the load. According to this assumption the non-structural parts carry only their own weight. Thus, architects and interior architects feel relaxed about replacing and removing these non-load bearing infill walls. This is the basic assumption behind the architectural flexibility of modern structural systems such as frames. However, every assumption requires the appropriate conditions to be present for the realization of that assumption. Structure and nonstructure cannot be abstracted from each other without considering the material relationship between them. According to the civil engineer Ersoy (1984), the earthquake problem in Turkey is very much related to such architectural design errors.

The relationship between the structural system and the infill walls are also studied by Papia, Cavaleri, Fossetti, 2003; Lee, Woo, 2002; and Negro, Verzeletti, 1996. The position of assuming a reinforced concrete frame to be the only load bearing part, can be clarified by considering the following statements of Ambrose and Vergun. (1985) "Use of rigid nonstructural elements in combination with flexible bracing systems is not impossible, but it needs care... Otherwise, the stiffer elements will absorb the load untill they fail and others take over."

According to Dowrick (1990), strong non-load bearing elements can co-exist with stiff frames, which contain shear walls. However, if the frame is flexible, strong non-load bearing infill walls must be separated from the frame. The San Fernando earthquake provides us with enough evidence about, and experience of, the relationship between flexible structural systems, and the rigid non-load bearing 
infill walls. (Freeman, Czarnecki, Honda, 1980) The laboratory experiments, which were carried out to determine the structural role of non-load bearing brick walls on reinforced concrete frames, also support these explanations. Under such conditions, the infill walls start forming struts. (Klingner, 1980) (Figure 5)

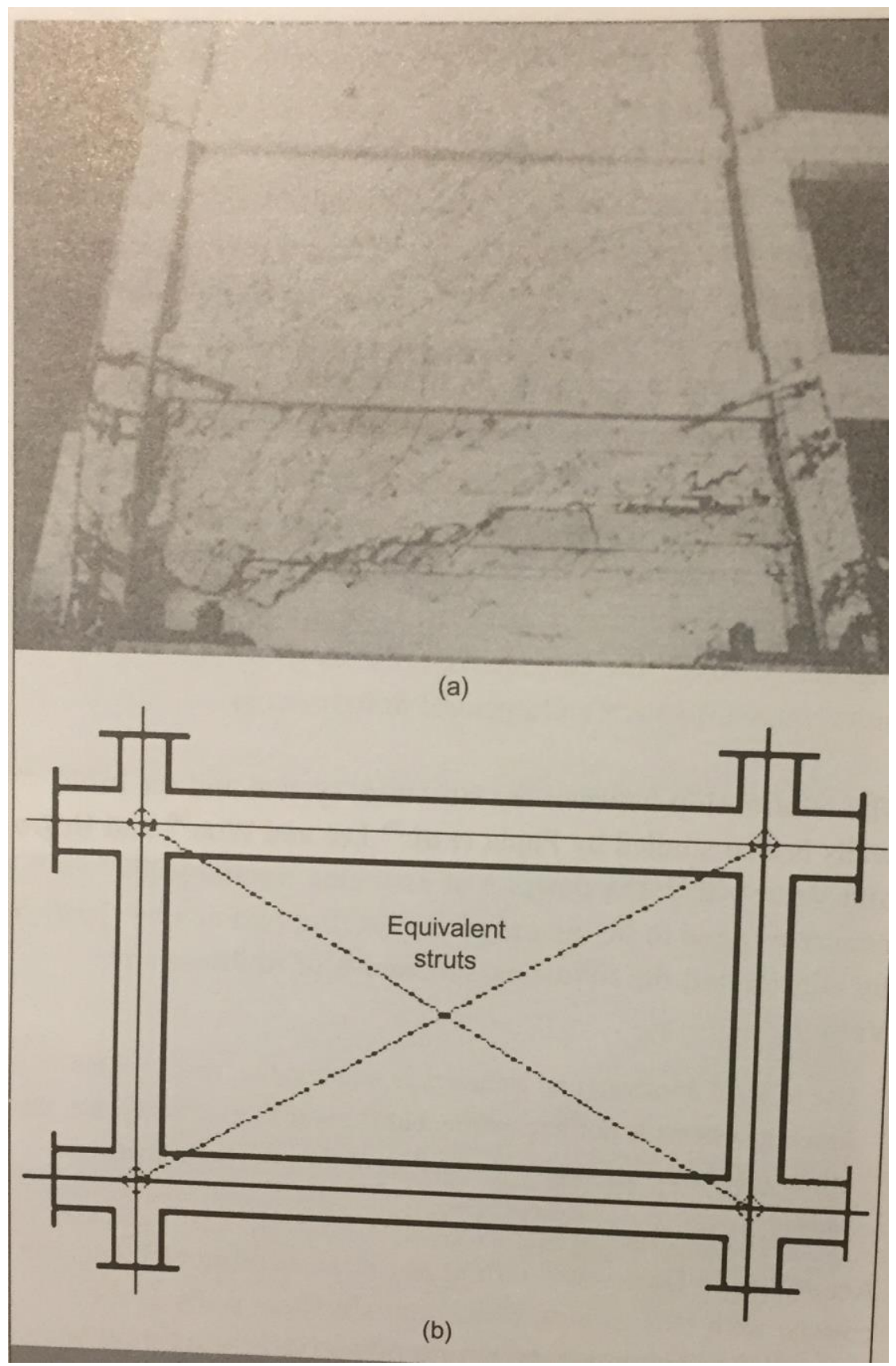

Figure 5. a. Development and crush of struts in an infill wall.

b. Analytical idealization of an infill wall as two equivalent struts. (Klingner, 1980)

\section{ARCHITECTURAL DESIGN AS THE CAUSE OF SOFT STOREY AND} SHORT COLUMN PROBLEMS. 
None of the references which are covered in this research, contain any serious information about those architectural design problems, which cause soft storey and short column problems. Structural engineering articles and reports, which are prepared after each earthquake give a detailed description of the structural problems, which have led to the damage during earthquakes, but they usually only offer a very rough and approximate opinion on the issue of architectural design being a cause of these problems. For example, it is usually suggested that the soft storey problem occurs because of the shop-window requirement, and that the short column problem also occurs because of the presence of gallery levels in the shops. This means that soft storey and short column problems in Turkey usually occur as a result of the functional requirements as dictated by the commercial usage of the buildings at the ground floor level. Although this is absolutely accurate, there are many other functional arrangements of the space which cause the same problems. Metaphorically speaking, ignorance or lack of knowledge about the less frequently occuring reasons for an illness, and consideration of only the most frequent causes, will result in a poor or inaccurate diagnosis.

According to the report produced by Istanbul Technical University, in respect of the Kocaeli earthquake (İTÜ, 1999), an important portion of the earthquake damage occured because of a lack of rigidity at ground floor level. Further indication of the gravity of the soft storey and short column problems in Turkey, is demonstrated by the following figures, which belong to the Erzincan earthquake: (Şengezer, 1999)

a. $54 \%$ of six storey reinforced concrete buildings were collapsed or heavily damaged,

b. $57 \%$ of three storey reinforced concrete 'corner buildings' (buildings, which are situated where two streets meet) were either collapsed or heavily damaged,

c. $100 \%$ of six storey reinforced concrete corner buildings were collapsed or heavily damaged.

The ground floor levels of all buildings, including the corner buildings, which are in commercial areas, are used for commercial activities. This means the elimination of walls and the use of large glass surfaces in order to provide shop windows. The other floor levels can be used either for business or residential 
purposes. However, the presence of commercial activities, such as shops, supermarkets etc., in the residential areas, usually only involve the ground floors of corner buildings. Consequently, the term 'corner building,' generally indicates the existence of commercial activity in all types of urban areas. Since it is known that the functional arrangement, which causes most of the collapses due to soft storey and short column problems, is as a result of the arrangement and design of the commercial spaces, it can be stated that the high rate of collapse of corner buildings could arguably be due to soft storey and short column problems.

As aforesaid the research, which is presented in this paper is carried out on a residential and a commercial street which contains reinforced concrete apartment buildings in Famagusta in Northern Cyprus. The percentages of the possible soft storey and short column problems in both streets are shown in Table 1. The figures in Table 1 have been compiled from external observation only. However, some other soft storey problems, which are present as a result of the removal of interior infill walls, might also exist.

\begin{tabular}{|c|c|c|c|c|c|c|}
\hline & $\begin{array}{l}\text { Soft } \\
\text { Storey } \\
\text { (SS) }\end{array}$ & $\begin{array}{l}\text { Short } \\
\text { Column } \\
\text { (SC) }\end{array}$ & $\begin{array}{l}\text { SC } \\
\text { (because of } \\
\text { walls) }\end{array}$ & $\begin{array}{l}\text { SC } \\
\text { (because of } \\
\text { structure) }\end{array}$ & $\begin{array}{l}\text { Buildings } \\
\text { with SS, } \\
\text { SC } \\
\text { problems }\end{array}$ & $\begin{array}{l}\text { Total } \\
\text { number } \\
\text { of } \\
\text { buildings }\end{array}$ \\
\hline $\begin{array}{l}\text { Residential } \\
\text { street }\end{array}$ & $\begin{array}{c}5 \\
23 \%\end{array}$ & $\begin{array}{c}5 \\
23 \%\end{array}$ & $\begin{array}{l}4 \\
18 \%\end{array}$ & $\begin{array}{c}3 \\
14 \%\end{array}$ & $\begin{array}{c}7 \\
32 \%\end{array}$ & 22 \\
\hline $\begin{array}{l}\text { Commercial } \\
\text { street }\end{array}$ & $\begin{array}{c}19 \\
95 \% \\
\end{array}$ & $\begin{array}{c}10 \\
50 \% \\
\end{array}$ & $\begin{array}{c}7 \\
35 \% \\
\end{array}$ & $\begin{array}{c}3 \\
15 \% \\
\end{array}$ & $\begin{array}{c}20 \\
100 \%\end{array}$ & 20 \\
\hline
\end{tabular}

Table 1. Percentages of possible soft storey and short column problems in a commercial and a residential street.

As can be seen from Table 1, the amount of soft storey and short column problems increases dramatically in the commercial street. However, the same problems also exist in many buildings in the residential area. Architectural design problems, which might cause the formation of soft storeys can be listed as follows:

1. Design of the entrance area with a large semi-open space, or with large windows,

2. Using the ground floor area as a semi-open space in shade,

3. Using the ground floor area as a semi-open car-parking area, 
4. Use of large and high shop windows,

5. Design of very large terraces on the intermediate floors.

Similarly, architectural design problems, which might cause the formation of short columns can be listed as follows:

1. Use of narrow WC windows, adjacent to the columns,

2. Design of a surrounding balcony with massive reinforced concrete balustrades and beams which leave very narrow openings,

3. Use of long and narrow windows,

4. Use of narrow windows in the upper parts of the large and high shop-windows,

5. Use of narrow windows for the car-parking and storage areas at basement levels,

6. Use of narrow windows for the gallery levels of the shops.

Both the soft storey and short column problems are very much related to the type of window design and other apertures in the buildings. Thus, the removal of nonload bearing infill walls, which is usually done for functional or aesthetic purposes, can specifically cause soft storey problems.

Tables 2 and Table 3 have been prepared in order to provide information about the percentages of the above architectural design problems, which might cause the formation of soft storeys and short columns in the reinforced concrete apartment buildings, in both commercial and residential streets.

\begin{tabular}{|l|ll|l|}
\hline & \multicolumn{2}{|l|}{ Residential street } & Commercial street \\
\hline $\begin{array}{l}\text { Having large terraces } \\
\text { and windows at the } \\
\text { entrance. }\end{array}$ & 1 & $13 \%$ & - \\
\hline $\begin{array}{l}\text { Use of ground floor as } \\
\text { the semi-open area. }\end{array}$ & 2 & $26 \%$ & - \\
\hline $\begin{array}{l}\text { Use of ground or } \\
\text { basement floor as open } \\
\text { car-parking area. }\end{array}$ & 3 & $39 \%$ & 6 \\
\hline $\begin{array}{l}\text { Use of large and high } \\
\text { shop windows. }\end{array}$ & 1 & $13 \%$ & 16 \\
\hline $\begin{array}{l}\text { Having large terraces at } \\
\text { the intermediate levels. }\end{array}$ & 1 & $13 \%$ & - \\
\hline
\end{tabular}

Table 2. Percentages of architectural design problems which might cause the formation of soft storeys. 


\begin{tabular}{|l|lr|ll|}
\hline & \multicolumn{2}{|l|}{ Residential street } & \multicolumn{2}{l|}{ Commercial street } \\
\hline $\begin{array}{l}\text { Balconies with high concrete } \\
\text { balustrades and deep beams. }\end{array}$ & \multicolumn{2}{|l|}{$17 \%$} & - & $20 \%$ \\
\hline $\begin{array}{l}\text { Use of narrow and long WC } \\
\text { windows. }\end{array}$ & 1 & $17 \%$ & 2 & $20 \%$ \\
\hline $\begin{array}{l}\text { Long and narrow windows at } \\
\text { the gallery levels of high } \\
\text { shops. }\end{array}$ & 1 & $17 \%$ & 2 & $30 \%$ \\
\hline $\begin{array}{l}\text { Long and narrow windows at } \\
\text { the top of high shop windows. }\end{array}$ & 1 & $17 \%$ & 3 & $30 \%$ \\
\hline $\begin{array}{l}\text { Long and narrow windows at } \\
\text { the basement level. }\end{array}$ & 1 & $17 \%$ & 3 & \\
\hline $\begin{array}{l}\text { Use of long and narrow } \\
\text { windows with other reasons. }\end{array}$ & 1 & $17 \%$ & - & \\
\hline
\end{tabular}

Table 3. Percentages of architectural design problems which might cause the formation of short columns.

As can be seen from Table 2, the architectural design problems which might cause the formation of soft storeys in the commercial street, are directly related to the requirements of shop design. However, shop design is not the only reason. In addition to the requirements of shop design, the presence of garages in the basement floors or behind the shops, also tend to cause soft storey problems. On the other hand, the architectural design problems, which might cause formation of soft storeys vary a lot in the residential street. Here, the existence of basement floor garages is the dominant problem amongst many others.

As can be seen from Table 3, the architectural design problems, which might cause the formation of short columns, vary in both the residential and commercial streets. However, the most important problems in the commercial street are the high ceiling levels of the shops, which require extra beams to support tall columns, and the positions of the strip-type basement windows.

Tables 2 and 3 show that the structural engineering literature, which is covered in this paper, naturally provides a rough analysis of, and opinion about the architectural design problems that may have caused soft storey and short column problems. The architectural problems, which are described by them are not accurate even for the commercial areas. There are various other architectural design problems which cause soft storey and short column problems, especially in residential areas. The problem must also be studied by architects. 


\section{SOLUTIONS FOR THE PROBLEM}

Solutions to soft storey and short column problems cannot be studied without considering the differences between the solutions for:

1. new buildings,

2. existing buildings,

2.1. with problems,

1.2. damaged buildings.

This paper does not cover the existing buildings which are damaged.

\subsection{SOLUTIONS FOR NEW BUILDINGS}

Much of the literature, which is studied in this paper (such as, Ambrose, Vergun, 1985; 1999; Dowrick, 1990; Paz, 1994; Ministry of Public Works and Settlement, 1997; Kubin, n.d.2) offers solutions to the problems of soft storey and short column incidence, for future buildings, but not for existing ones. These solutions are classified in three main groups for the purposes of this paper. These are:

1. Preliminary architectural design solutions, which can be realized only by architects.

2. Application project detailing, in other words 'seismic detailing' of structures, which can be realized both by architects and structural engineers.

3. Appropriate mathematical modelling of the structure, which can be realized only by structural engineers. Architects can have no role in such processes.

Consequently, it can be stated that architectural solutions to soft storey and short column problems cover the preliminary architectural design solutions and `seismic detailing.' On the other hand, structural engineering solutions cover appropriate mathematical modelling and 'seismic detailing.' Seismic detailing can both be categorized as an architectural solution, and as a structural engineering solution depending on the identification of the problem by the architect or by the structural engineer. According to the existing codes of Turkey and Northern Cyprus, it is expected that only the structural engineer will identify the earthquake problems of 
buildings. Thus, 'seismic detailing,' currently, seems to be viewed as being held amongst the structural engineering solutions, and not in the architectural solutions.

\section{Preliminary Architectural Design Solutions}

Garcia's book (2002) forms a collection of earthquake resistant architecture which can also be acknowledged as examples of good architecture, such as The European Parliament Building. According to Ambrose and Vergun (1985, 1999), the following preliminary design solutions may be utilised to combat the problems of soft storey.

1. Bracing some of the open bays, (Figure 6.a)

2. Keeping the building plan periphery open, whilst providing a rigidly braced interior, (Figure 6.b)

3. Using tapered or arched forms for the ground floor columns, (Figure 6.d)

4. Developing a rigid first storey as an upward extension of a heavy foundation structure. (Figure 6.e)

5. Increasing the number of ground floor columns. (Figure 6.c)

6. Dorwick (1990) suggests the use of shear walls effectively in all directions in order to increase the rigidity of the frame. This is one of the solutions that is accepted by the building codes of Japan, Israel and Romania. (Paz, 1994)

7. In addition to these preliminary design solutions, one more suggestion can be added to them; that of separating the axis of non-load bearing walls from the axis of the structural frame, as in the designs of Le Corbusier, who has extensively used "strip windows" as well as "pilotis," which has set the precedent for the most frequent reasons for soft storey and short column formations currently. (Figure 7)

The first, sixth and seventh of these proposed solutions are also valid for the elimination of short column problems. 


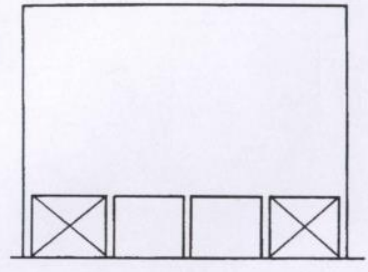

(a)

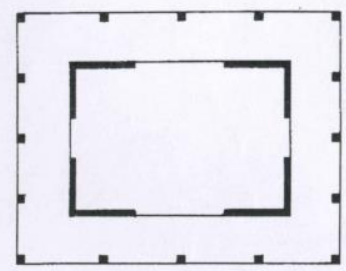

(b)

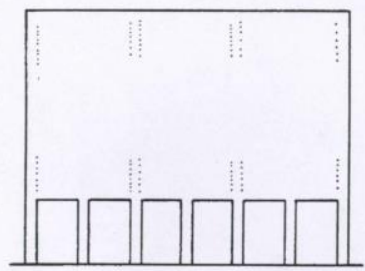

(c)

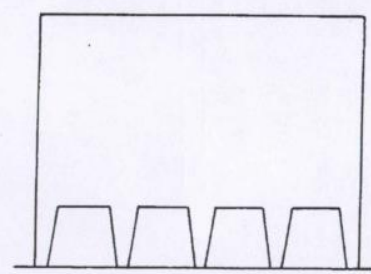

$(d)$

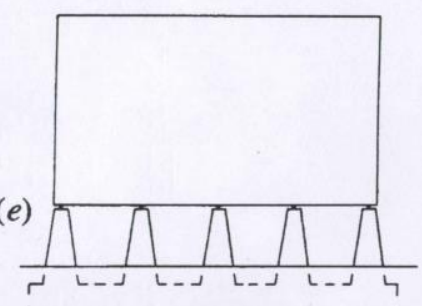

L...................

Figure 6. Floor design to combat soft storey formation. (Ambrose, Vergun, 1999)

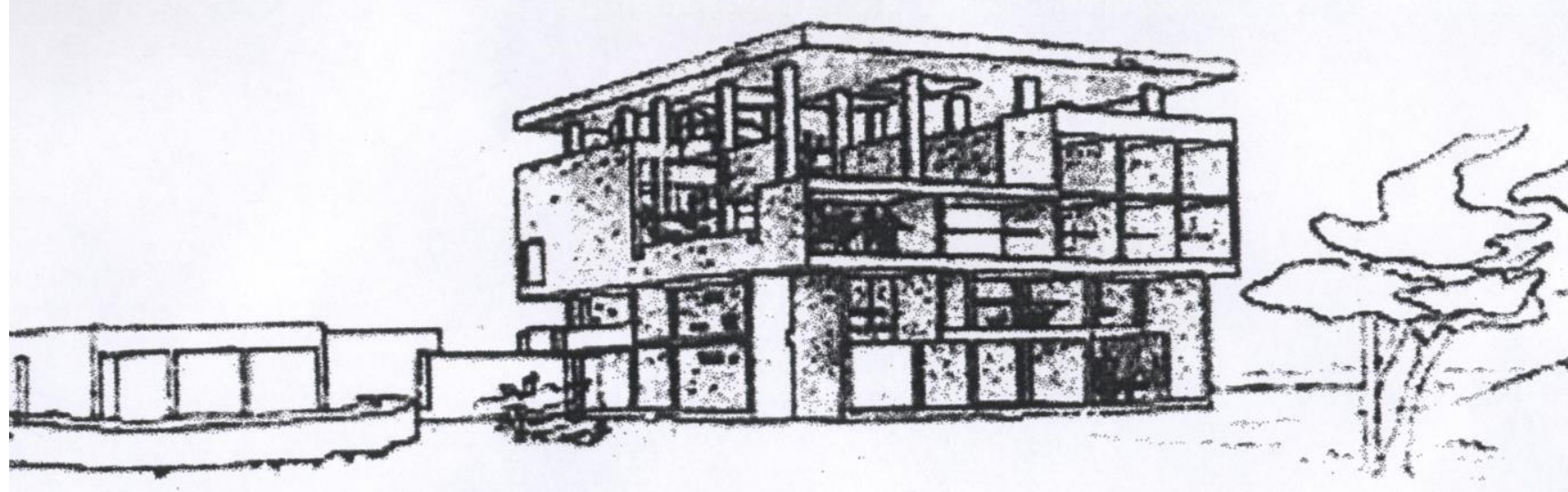

Figure 7. An example of the separation of the axis of nonstructure from the axis of structure.

\section{Seismic Detailing of Structure}

Seismic detailing of structure includes control joints, motion isolation joints, energy absorbing devices and base isolation of the buildings. Here, only the joint types between the infill walls and structure are explained, because only these can be direct solutions for soft storey and short column problems. Infill walls may be either integrated into the structure, or separated from it. Dowrick (1990) proposes integration, but only if the structural system is stiff because of the existence of shear walls. (Figure 8) Separation of infill from structure is necessary, only if the building structure is a flexible frame. (Figure 9) 


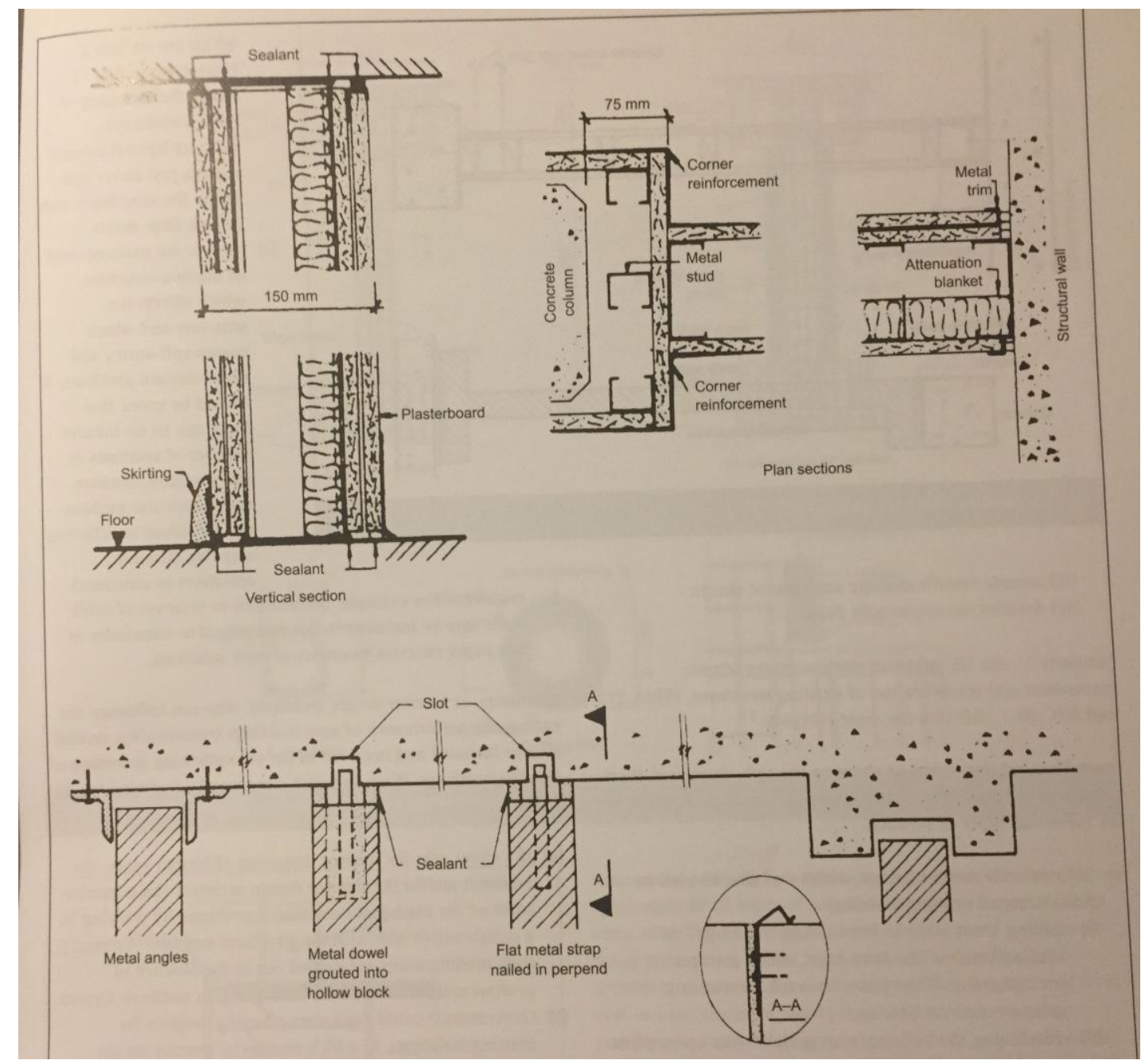

Figure 8. Integrating infill with structure. (Dowrick, 1990)

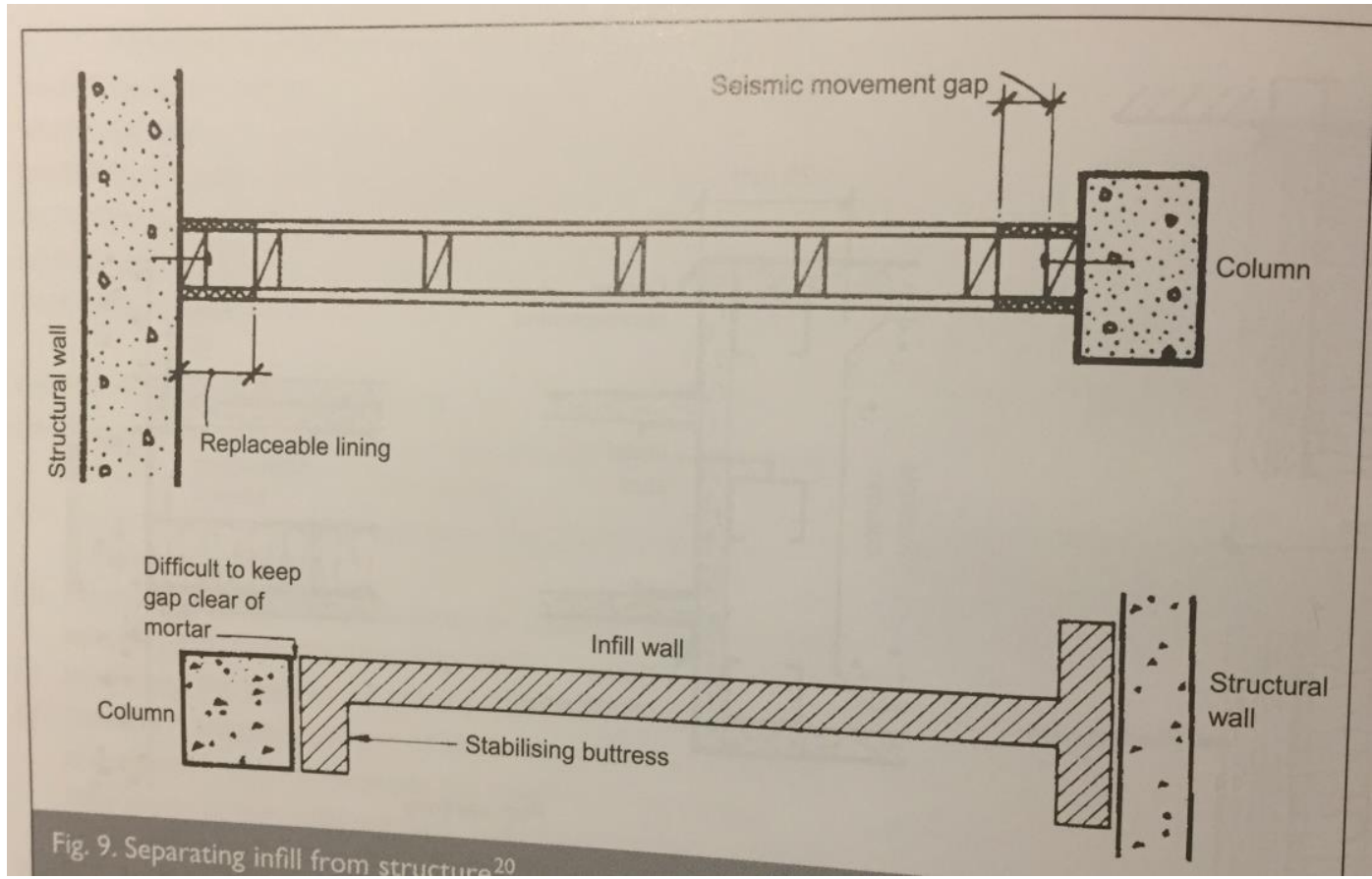

Figure 9. Separating infill from structure. (Dowrick, 1990) 
The wall, which is separated from the structure has to be designed in such a way as to reduce any problems arising from its separation from the reinforced concrete frame. There must be 20 to $40 \mathrm{~mm}$ distance between the structure and the infill wall for structural purposes, and this requires care during construction. The stability of this independent infill wall against the out of plane forces, must also be realized. The material used between the structure and the wall is important for the purposes of adequate heat and sound insulation. 'Seismic detailing' is one of the solutions to the problem, which is proposed by Mexico City building code. (Paz, 1994)

\section{Appropriate Mathematical Modelling of Structure}

Increasing the strength and stiffness of the columns of certain storeys (specifically the ground floor columns) during the structural design of new buildings, can be accepted as a result of appropriate mathematical modelling of structure in order to eliminate the soft storey and short column problems. This solution might cause an increase in the cross-sectional area of certain columns, and an increase in the amount of reinforcement due to the application of specific rules which are covered by building codes and specifications.

The proposed solution of the Turkish government in order to combat earthquake damage has been to produce a building code, which only covers appropriate mathematical modeling of structure which can be provided only by structural engineers, and which simplifies the building process and decreases the costs. The 1997 renewal of the building code covers the soft storey and short column problems in the same manner. It is mentioned in the specifications that: “.... appropriate measures should be taken to avoid the negative effects of an abrupt decrease in stiffness and strength due to the removal of infill walls from some of the storeys and in particular from the first storey of buildings which may possess considerable stiffness in their own planes, even though they are not taken into account in the analysis." (Ministry of Public Works and Settlement, 1997) It is the same in the Northern Cyprus building code. If a soft storey problem exists in the project, specifications propose changes in the method of analysis. Similarly, the existence of a short column problem in the project causes a difference in the 
shear force calculation. According to Kubin, it is enough to follow the rules of this building code and specifications in order to eliminate all types of earthquake problems. (Kubin, n.d.2.) However, in Turkey, the code and specifications are never adhered to, especially in respect of the building contractors.

\subsection{STRENGTHENING OF EXISTING BUILDINGS}

Solutions for the earthquake problems of existing buildings are generally called 'strengthening' or 'retrofitting.' According to Ambrose and Vergun (1999), these solutions might cover the reduction of the forces, increasing the quality of the existing construction, adding strength to the lateral resistant system and separating non-structure from structure. There are various types of strengthening and, therefore, strengthening can be applied in a variety of situations, such as the following:

1. Strengthening of the damaged buildings, which is not the subject of this paper.

2. Strengthening of the buildings, which have not yet been damaged. Retrofitting of the vulnerable existing structures is defined as a need in Eurocode- 8 . This includes the following steps:

" a. data and information collection,

b. seismic evaluation,

c. seismic retrofit strategy and scheme design,

d. detailed seismic retrofit design."

Similarly "...the US guideline documents on seismic assessment and rehabilitation of existing structures, FEMA 273 and ATC 40..." fall into the same category. (Lubkowski, Duan, 2001;)

Strengthening to prevent or shore up the soft storey and short column problems of the second group of buildings might cover the following types of solutions:

1. Solutions for the new buildings, which can also be used in the non-damaged existing buildings:

a. Adding shear walls to the existing building (see Miller, Reaveley, 1996), or bracing some of the open bays, which requires strengthening of the joints between the existing structure and the bracing,

b. Re-designing the building plan periphery as open, whilst providing a 
rigidly braced interior with the help of rigid infill walls, (Ambrose, Vergun, 1999)

c. Separating all infill from the structure by providing 'seismic details.'

These are the solutions which can also be realized by interior architects through the preparation of interior design projects for the existing buildings.

2. The strengthening of columns, beams and connections is usually applied to damaged buildings. However, some of these solutions may also be useful for the non-damaged buildings, if the quality of concrete is bad, and the dimensions of structural members are too slender. There are various ways of strengthening columns, beams and connections. Solutions, such as the use of epoxy pressure injection (see Filiatrault, Lebrun, 1996) and the use of shotcrete (see Warner, 1996) can be employed, which will increase the quality of the concrete.

Increasing the strength of the elements and joints by making them larger is another alternative. The use of jackets, strips, wraps, or plates, which are made of steel, carbon fibre, and ferrocement are examples of this. (see Ambrose, Vergun, 1999; Katsuki, Takiguchi, Abdullah, 2001; Sabnis et.al., 1996; Parra-Montesinos, Wight, 2001; Ghobarah, Galal, 2004; Martnezrueda, Elnashai, 1995) Figure 10 shows shear strengthening of reinforced concrete columns by using ferrocement jackets. Here, the jacket contains layers of wire mesh, which are put in a cement paste. Figure 11 shows the wrapping of those (reinforced concrete hybrid) column regions just above and below the steel beam with carbon fibre sheets. 

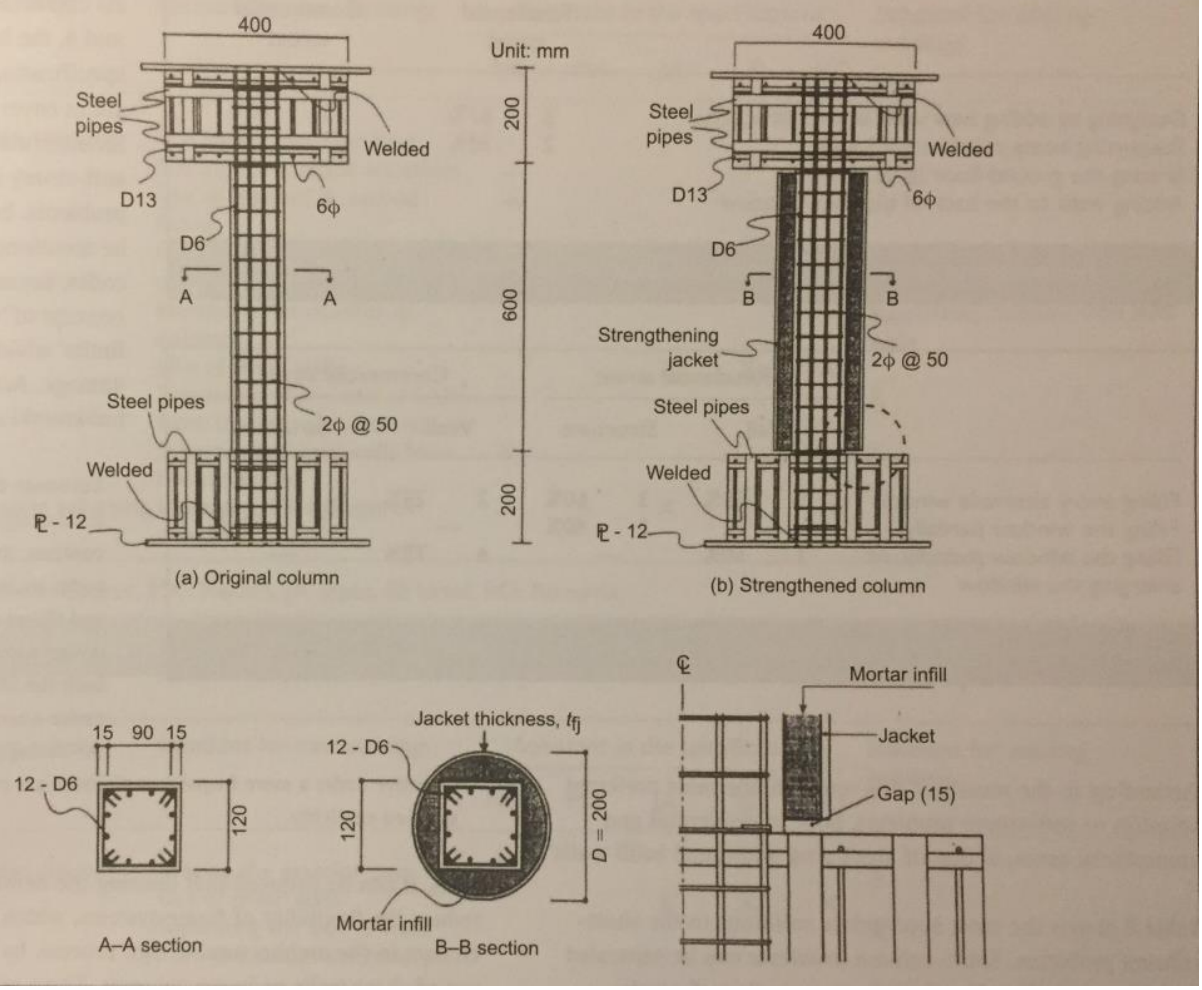

Figure 10. Strengthening of a column by using a ferrocement jacket. (Katsuki, Takiguchi, Abdullah, 2001) 

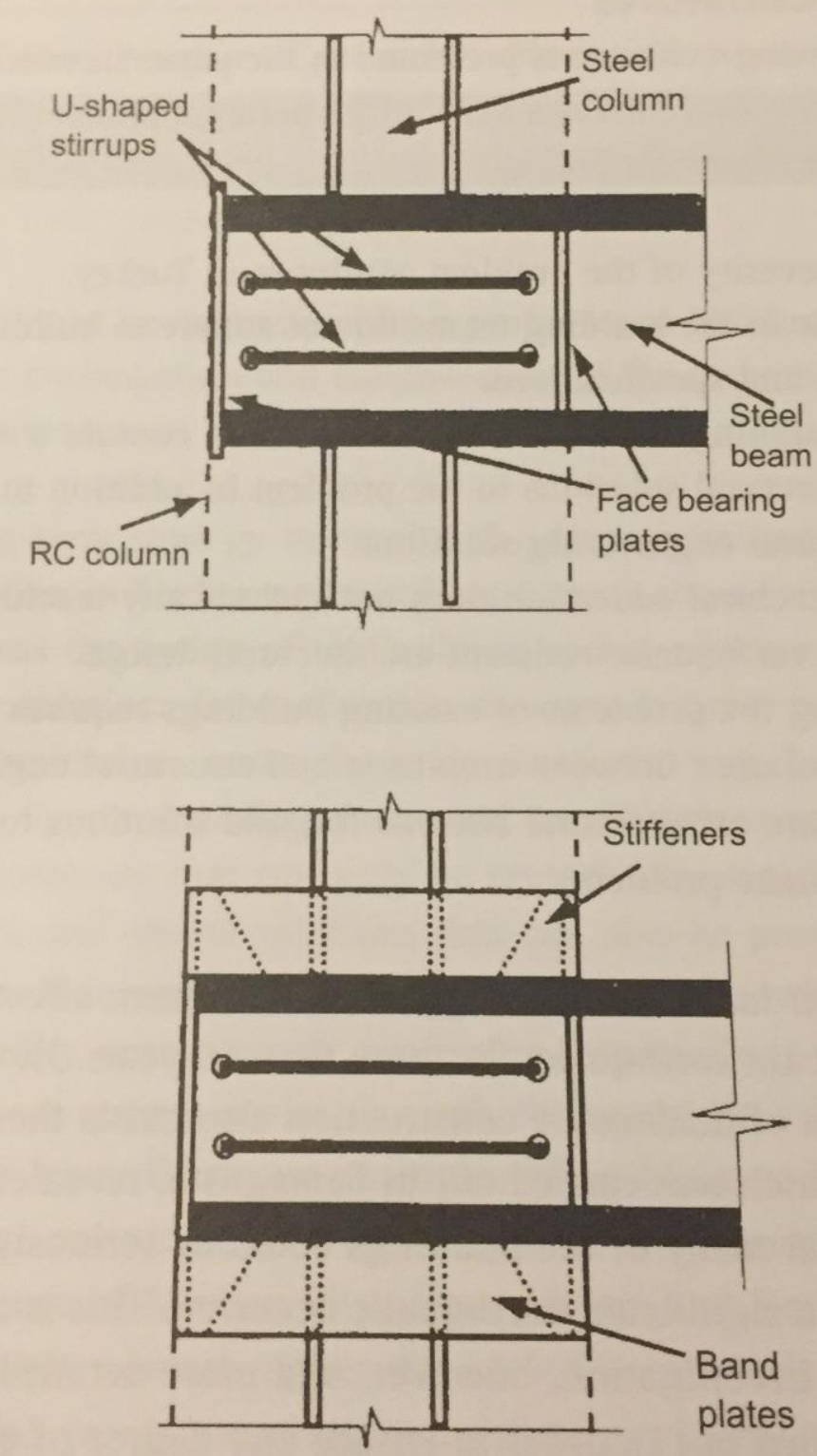

Figure 11. Wrapping RC hybrid column with carbon fibre sheets. (ParraMontesinos, Wight, 2001)

3. 'Repair' (or maintenance) of the non-structure, which affects the structure and which causes soft storey and short column problems.

It should be stated that there can be an infinite number of solutions in this category, because each particular problem can be solved in differing ways by different architects or structural engineers. For example, the addition or removal of infill walls may be included in this category. The following remainder of this paper contains examples of such solutions. 
Architects, or interior architects, who can influence the earthquake performance of new buildings considerably, should also be included, and involved in the strengthening processes of existing buildings. Ways in which they may be included are as follows:

- If a client asks for interior designing of his/her space, the architect and/or the interior architect can eliminate some of the earthquake resistance problems by working in a collaborative way with the structural engineer. Currently, such modifications are carried out in the absence of professional advice both in Turkey and Northern Cyprus.

- A government may decide to fund a strengthening project for the existing buildings, in which architects, interior architects and structural engineers can collaborate together. This process can save a lot of lives, because many of the currently existing buildings have serious problems, which could be relatively easily resolved.

All the strengthening methods, which are listed above require different levels of economic power if they are to be realized. The first two groups are the most expensive, whilst the third, is the least. On the other hand, the selection of the best solution is very much related to the economic power of the owner. Consequently, the best way of determining the most appropriate solution for each case is to create a participatory relationship with the owners of the problem spaces. However, this approach may be worthy of a more detailed research study, which can subsequently provide more accuracy and certainty in the final diagnosis of the problems. Since this paper sets out to provide only a preliminary research study, which can, therefore, essentially only provide a basis for more detailed, and advanced research, the researchers should determine the most appropriate solution for each problem situation by considering the relationship between the economic status of the owner and the function of the space. This is effected in this research by assuming that the buildings on the commercial street in Famagusta are appropriate for the application of all types of solutions including the more costly ones, whilst the buildings on the residential street are seen as being appropriate for the least costly solutions. Since the architectural reasons for the problems differ considerably from case to case, the most appropriate solutions can only be provided in a somewhat generalized manner, as a result of the research carried out 
on the existing buildings. Tables 4 and 5 contain the percentages of the most appropriate architectural solutions to the problems, which were determined in the method as described above.

\begin{tabular}{|l|lc|cc|}
\hline & Residential street & Commercial street & \\
\hline $\begin{array}{l}\text { Designing by adding } \\
\text { new walls in two } \\
\text { directions. }\end{array}$ & 3 & $67 \%$ & 15 & $68 \%$ \\
\hline $\begin{array}{l}\text { Supporting some } \\
\text { columns with walls. }\end{array}$ & 2 & $33 \%$ & 2 & $9 \%$ \\
\hline $\begin{array}{l}\text { Bracing the ground floor } \\
\text { level structure. }\end{array}$ & - & 1 & $5 \%$ \\
\hline $\begin{array}{l}\text { Adding walls to the back } \\
\text { of the shop window. }\end{array}$ & - & 4 & $18 \%$ \\
\hline
\end{tabular}

Table 4. Percentages of architectural solutions to the soft storey problems.

\begin{tabular}{|l|ll|ll|l|l|l|}
\hline & \multicolumn{2}{|l|}{ Residential street } & \multicolumn{3}{l|}{ Commercial street } \\
\cline { 2 - 7 } & Wall & Structure & \multicolumn{2}{|l|}{ Wall } & Structure \\
\hline $\begin{array}{l}\text { Filling every } \\
\text { alternate } \\
\text { window. }\end{array}$ & 3 & $50 \%$ & 3 & $60 \%$ & 2 & $25 \%$ & - \\
\hline $\begin{array}{l}\text { Filling the } \\
\text { window } \\
\text { partially. }\end{array}$ & - & 2 & $40 \%$ & - & 3 & $100 \%$ \\
\hline $\begin{array}{l}\text { Filling the } \\
\text { window } \\
\text { partially, or } \\
\text { enlarging the } \\
\text { window. }\end{array}$ & 3 & $50 \%$ & - & 6 & $75 \%$ & - & \\
\hline
\end{tabular}

Table 5. Percentages of architectural solutions to the short column problems.

As can be seen from Table 4, the most appropriate solutions to the soft storey problem may sometimes actually be resolved by a relatively simple design alteration. Conversely the design activity may also require a very complicated solution. These solutions are as follows:

1. Designing additional infill walls equally in two directions in order to reduce the overall flexibility of the ground floor level,

2. Supporting some of the columns with infill walls,

3. Adding walls to the back of the shop window in order to reduce the flexibility of the ground floor,

4. Using bracing elements between the ground floor members of the structure. 
The first three of the above solutions can be described as the "repair" type of solutions for non-damaged buildings. According to the results of this research, the most preferred solution to soft storey problems, both in residential and commercial areas is that of "designing additional infill walls."

Table 5, shows the most appropriate solutions to the short column problems. Short column problems can be separated into two categories. The first category is that of the short column problem due to a poorly conceived structural member layout (mentioned as "structure" on the table). The second category is that of the short column problem due to the wrong use of infill walls to create strip windows (mentioned as "wall" on the table). As seen from Table 5, the first type of short column is usually seen in residential areas, whilst the second type frequently appears in commercial areas.

According to Table 5, the most appropriate solutions to short column problems can be listed as follows:

1. Filling in every alternate window with infill walls,

2. Partially filling in the windows in order to eliminate the shear concentration in the column,

3. Partially filling in the window with infill walls, or increasing the height of the window.

All the above solutions can be described as the 'repair' type of solution for nondamaged buildings. According to the results of this research, the most appropriate solutions for the short column problem concentrates on: "partial filling of the strip window" in the commercial areas, whilst in the residential areas the focus is on "filling every alternate window."

\subsection{ARCHITECTURAL SOLUTIONS AND THE SOLUTIONS IN THE BUILDING CODES AND SPECIFICATIONS}

Tables 6 and 7 can be used to compare the solutions for the soft storey and short column problems, which are proposed by the codes, with the solutions that are 
proposed in this research. These tables cover the building codes of Turkey and Northern Cyprus together with the codes of Mexico City, Japan, Israel and Romania.

\begin{tabular}{|c|c|c|c|c|c|c|c|}
\hline \multirow{2}{*}{$\begin{array}{l}\begin{array}{l}\text { Solutions for } \\
\text { "soft storey" } \\
\text { problem }\end{array} \\
\begin{array}{l}\text { Architectural design } \\
\text { solutions }\end{array}\end{array}$} & \multirow{2}{*}{$\begin{array}{l}\text { Solutions for new } \\
\text { buildings } \\
\begin{array}{l}\text { Bracing the exterior } \\
\text { bays }\end{array}\end{array}$} & \multicolumn{5}{|c|}{$\begin{array}{l}\text { Solutions in the } \\
\text { specifications } \\
\text { NC MX JA IS RO }\end{array}$} & $\begin{array}{l}\text { Solutions for existing } \\
\text { buildings }\end{array}$ \\
\hline & & & & & & & $X$ \\
\hline & $\begin{array}{l}\text { Bracing the interior } \\
\text { members }\end{array}$ & & & & & & $X$ \\
\hline & $\begin{array}{l}\text { Use of tapered or } \\
\text { arched forms }\end{array}$ & & & & & & \\
\hline & $\begin{array}{l}\text { Ground floor as an } \\
\text { extension of the } \\
\text { foundation }\end{array}$ & & & & & & Adding infill walls \\
\hline & $\begin{array}{l}\text { Increasing the } \\
\text { number of columns }\end{array}$ & & & & & & $\begin{array}{l}\text { Supporting columns } \\
\text { with infill walls }\end{array}$ \\
\hline & $\begin{array}{l}\text { Use of } \\
\text { shear walls }\end{array}$ & & & $\mathrm{X}$ & $\mathrm{X}$ & $\mathrm{X}$ & \\
\hline & $\begin{array}{l}\text { Separation of the axis } \\
\text { of walls from the axis } \\
\text { of structure }\end{array}$ & & & & & & $\mathrm{X}$ \\
\hline $\begin{array}{l}\text { Seismic } \\
\text { Detailing }\end{array}$ & $\begin{array}{l}\text { Separation of infill } \\
\text { walls from the } \\
\text { structure }\end{array}$ & & $\mathrm{X}$ & & & & $X$ \\
\hline $\begin{array}{l}\text { Structural } \\
\text { engineering solutions }\end{array}$ & $\begin{array}{l}\text { Increasing the } \\
\text { stiffness of columns }\end{array}$ & $\mathrm{X}$ & $\mathrm{X}$ & $\mathrm{X}$ & $\bar{X}$ & $\mathrm{X}$ & \\
\hline
\end{tabular}

NC: Turkey, Northern Cyprus,

MX: Mexico, JA: Japan, IS: Israel, RO: Romania.

Table 6. Solutions for soft storey problems.

\begin{tabular}{|l|l|l|l|l|l|l|l|}
\hline $\begin{array}{l}\text { Solutions for short } \\
\text { column problem }\end{array}$ & $\begin{array}{l}\text { Solutions for new } \\
\text { buildings }\end{array}$ & \multicolumn{3}{|l|}{$\begin{array}{l}\text { Solutions in the } \\
\text { specifications } \\
\text { NC MX JA IS RO }\end{array}$} & \multicolumn{2}{l|}{$\begin{array}{l}\text { Solutions for existing } \\
\text { buildings }\end{array}$} \\
\hline $\begin{array}{l}\text { Architectural design } \\
\text { solutions }\end{array}$ & $\begin{array}{l}\text { Bracing the exterior } \\
\text { bays }\end{array}$ & & & & & & \\
\cline { 2 - 7 } & $\begin{array}{l}\text { Use of } \\
\text { shear walls }\end{array}$ & & & X & X & X & \\
\hline & $\begin{array}{l}\text { Separating the axis of } \\
\text { walls from the axis of } \\
\text { columns }\end{array}$ & & & & & & X \\
\hline & & & & & & & $\begin{array}{l}\text { Enlarging the } \\
\text { windows }\end{array}$ \\
\hline & & & & & & & $\begin{array}{l}\text { Filling in the } \\
\text { windows }\end{array}$ \\
\hline Seismic & Separation of the & & & & & & \\
\hline
\end{tabular}




\begin{tabular}{|l|l|l|l|l|l|l|l|}
\hline detailing & $\begin{array}{l}\text { infill wall from the } \\
\text { structure }\end{array}$ & & $\mathrm{X}$ & & & & \\
\hline $\begin{array}{l}\text { Structural } \\
\text { engineering solutions }\end{array}$ & & $\mathrm{X}$ & $\mathrm{X}$ & $\mathrm{X}$ & $\mathrm{X}$ & $\mathrm{X}$ & $\mathrm{X}$ \\
\hline
\end{tabular}

NC: Turkey, Northern Cyprus,

MX: Mexico, JA: Japan, IS: Israel, RO: Romania.

Table 7. Solutions for short column problems.

As can be seen from Tables 6 and 7, the building codes and specifications of four nation states cover some architectural solutions for soft storey and short column problems. Eurocode- 8 can also be mentioned together with these codes, because it changes the concept of "deformation limits" which minimize the damage. According to Lubkowski and Duan (2001) "Eurocode-8.... adopts a one level design procedure... In contrast, the seismic design codes in Japan, New Zeland and China adopt a two level design procedure in which both the life safety objective under a rare earthquake and the damage limitation objective under a more frequent earthquake are required to be satisfied explicitly..." Thus, it can be deduced that the limit of deformation should cause a decrease in the flexibility of frame systems, which in turn, causes a change in the architectural design process, by increasing the use of shear walls or larger columns. These codes demonstrate that it is possible to have more than one hypothesis for the solutions of these problems.

\section{CONCLUSION}

The following evidence is presented in the paper in order to demonstrate that Turkey's earthquake policy might cause further problems for Turkey:

1. The severity of the problem continues in Turkey.

2. People in the building teams do not adhere to building codes and specifications.

3. The building codes of some countries do contain some architectural solutions to the problem in addition to structural engineering solutions.

4. Architectural education does not include any teaching about earthquake resistant architectural design.

5. Solving the problems of the existing buildings requires collaboration between architects and structural engineers.

6. There are architectural reasons for, and solutions to, earthquake problems. 
On the other hand, Northern Cyprus has not been affected by any significant earthquake for more than sixty years. However, the problem of inadequate construction also exists in Northern Cyprus. The research, which was carried out there, in Famagusta, revealed some evidence, which showed that many of the buildings could be seriously damaged if a significant earthquake occurred. However, this is a preliminary investigation, and more detailed research must be carried out in order to ensure any degree of certainty and accuracy. Such research should cover mathematical data collection, seismic evaluation with the support of structural analysis, scheme design and detailed design. Solutions to each problem must be determined by a professional building team, with the participation and collaboration of the owners of the problem spaces.

The long term strategy to combat the damage caused by earthquakes in Turkey and Northern Cyprus should encompass, of course, the design of the building codes, which propose multiple solutions for earthquake damage in order to combine all related professions under the same social strategy. Turkish and Northern Cypriot building codes and specifications contain the type of solutions which can only be provided by structural engineers, and ignore solutions which can also be provided by architects. However, it is not in any way adequate to leave all this responsibility with only one profession, especially if the problem is a severe, social one, which cannot be solved by codes and laws. There are examples of building codes, which cover some solutions, which can be provided by architects. These are the Mexico City, Japan, Israel, and Romanian building codes. They contain either the use of shear walls or construction joints as solutions to these problems in addition to those solutions, which can be provided only by structural engineers. Eurocode- 8 also considers the effects of architectural design on earthquake resistance. (Paz, 1994; Lubkowski, Duan, 2001)

This paper shows that:

1. The reasons for soft storey and short column problems can be explained in terms of architecture as well as structural engineering.

2. The soft storey and short column problems might appear in buildings, which have very different functions, and for many different reasons. 
3. There are multiple solutions to these problems, which cover the architectural design process at various levels, as well as the solutions, which can only be realized by structural engineers.

According to the results of this research it can be stated that:

1. The building codes and specifications of Turkey and Northern Cyprus should contain multiple solutions to earthquake problems, including architectural solutions. This is necessary in order to create a more collaborative form of team work between structural engineers and architects.

2. Further measures must be taken to enforce the relevant laws in order to ensure that people involved in the construction business adhere to the building codes.

3. There must be a program that enables retrofitting for the existing building stock, in order to improve their earthquake resistance. This is urgently necessary in many cities in Turkey in order to save lives in the future. These same points apply to Northern Cyprus in view of the anticipated process of unification with the European Union. Eurocodes-8, part 3, defines a need for the retrofitting of the vulnerable existing structures. (ECS, 2000)

4. Architectural education curricula in Turkey and Northern Cyprus should include the subject and teaching of "earthquake resistant architectural design."

\section{REFERENCES}

Anon, (2003) "Eurocodes - The New Design Environment." PI Civil Engineering. 156(3). August.

Akcansa Ltd., (n.d.). http://www.akcansa.com.tr/hb_yanlisdogru.htm (7.2002)

Ambrose,J.,Vergun,D., (1985). Seismic Design of Buildings. John Wiley and Sons Inc. Canada.

Ambrose,J.,Vergun,D., (1995). Simplified Building Design fOor Wind and Earthquake Forces. John Wiley and Sons. New York. 
Ambrose,J.,Vergun,D., (1999). Design for Earthquakes. John Wiley and Sons Inc. Canada.

Brochure of Northern Cyprus Turkish Republic Civil Defense Organisation. sivilsavunmakktc.com

Can,Ö., (1997) Assesment of Seismic Hazard for Cyprus. Unpublished Masters thesis. Eastern Mediterranean University. July.

Cyprus Civil Engineering and Architects Association. (1992) Seismic Code for Reinforced Concrete Structures. Nicosia.

Davis,I., (1978) Shelter and Disaster. Oxford Polytechnic Press. Oxford.

Dolsek,M., Fajfar,P., (2001) "Soft Storey Effects in Uniformly Infilled Reinforced Concrete Frames." Journal of Earthquake Engineering. 5 (1) January. p.1.

Dowrick, D. (1990). Earthquake Resistant Design. John Wiley and Sons. 2nd edition. Essex GB.

Earthquake Engineering New Zeland, (n.d.).

http://www.earthquakeengineering.com/case_studies/1.1.shtml (7.2002)

ECS European Committee for Standardization. (2000) Eurocode 8: Design of Structures for Earthquake Resistance. Draft no: 1.

http://www.geosuport.com/web/pdf/Eurocodigo\%208.pdf

EERI, (2002). http://www.eeri.org/earthquakes/Reconn/Iran02/iran0602.html (7.2002)

Erdik,M., Avc1,J.S., (1999). 'İstanbul İçin Deprem Tehlikesi ve Hasar Senaryosu." İstanbul. No:31. s.63.

Ergünay,O., Yurdatapan,O., (1973) Sismisite Çalışmaları ve Kıbrıs’ın Sismisitesi Hakkında bir Inceleme. Bayındırlık ve İskan Bakanlığı Deprem Araştırma Dairesi. Yayınlanmamış Araştırma. Ankara.

Ersoy,U., (1984). 'Depreme Dayanıklı Betonarme Yapılar - Temel İlkeler.' Erzurum Depremi Sempozyumu. Bayındırlık ve İskan Bakanlığı.

Filiatrault,A., Lebrun,I., (1996) "Seismic Rehabilitation of Reinforced Concrete Joints by Epoxy Pressure Injection Technique." in Seismic Rehabilitation of Concrete Structures. (Ed: Sabnis,G.M., Shroff,A.C., Kahn,L.F.) ACI, Michigan.

Freeman,S.A., Czarnecki,R.M., Honda,K.K., (1980) 'Significance of Stiffness Assumptions on Lateral Force Criteria.' Reinforced Concrete Structures Subjected to Wind and Earthquake Forces. American Concrete Institude. Detroit. p.437.

Garcia,B., (2002). Deprem Mimarlığı, Depremden Korunmak İçin Yeni İnşa Teknikleri. Tasarım Yayın Grubu. İstanbul. 
Ghobarah,A., Galal,K.E., (2004) "Seismic Rehabilitation of Short Rectangular RC Columns." Journal of Earthquake Engineering. 8 (1) January. p.45.

Hu,Y-X., Liu,S-C., Dong,W., (1996). Earthquake Engineering. E and FN Spon. Oxford.

İTÜ, (1999). http://www.belgenet.com/deprem/depremitu.html (7.2002)

Katsuki, Takiguchi, Abdullah, (2001) "Shear Strengthening of Reinforced Concrete Columns Using Ferrocement Jacket." ACI Structural Journal. 98 (5) September-October. p.697.

Key,D., (1988). Earthquake Design Practice for Buildings. Thomas Telford. London.

Klingner,R.E., (1980). 'Mathematical Framing of Infilled Frames.' Reinforced Concrete Structures Subjected to Wind and Earthquake Forces. American Concrete Institute. Detroit. p.1.

Kubin,J., (n.d.1). http://www.sayisalgrafik.com/gazete/vol04no04/m01.htm (7.2002)

Kubin,J., (n.d.2). http://www.sayisalgrafik.com/gazete/vol04no03/s07/m01.htm (7.2002)

Lee,H.S., Woo,S.W., (2002) "Effect of Masonry Infills on Seismic Performance of a 3 Storey R/C Frame with Non-seismic Detailing." Earthquake Engineering Structures. 31 (2) February. p.353.

Lubkowski,Z., Duan,X., (2001) "EN1998 Eurocode 8: Design of Structures for Earthquake Resistance.” Civil Engineering. 144. November. p.55.

Martinezrueda,J.E., Elnashai,A.S., (1995) "A Novel Technique for the Retrofiting of Reinforced Concrete Structures.” Engineering Structures. 17 (5) June. p.359.

Miller,J.T., Reaveley,L.D., (1996) "Historic Hotel Utah Remodel and Upgrade." in Seismic Rehabilitation of Concrete Structures. (Ed: Sabnis,G.M., Shroff,A.C., Kahn,L.F.) ACI, Michigan.

Ministry of Public Works and Settlement Government of the Republic of Turkey. Specification for Structures to be Built in Disaster Areas. Part III.Earthquake Disaster Prevention. (Trans:M.N.Aydınoğlu). Issued on: 2.9.1997. Official Gazette No: 23098.

NCREE, (n.d.). http://www.ncree.gov.tw/eq0331/songshan-5.htm (7.2002)

Negro,P., Verzeletti,G., (1996) "Effect of Infills on the Global Behavior of R/C Frames." Earthquake Engineering Structures. 25 (8) August. p.253. 
Özbilen,M., (2004) Inadequate Applications of Construction Industry in Northern Cyprus and Recomendations. Unpublished Masters Thesis. Eastern Mediterranean University. January.

Papia,M., Cavaleri,L., Fossetti,M., (2003) "Infilled Frames: Developments in the Evaluation of the Stiffening Effect of Infills." Structural Engineering Mechanics. 16 (6) December. p.675.

Parra-Montesinos,G., Wight,J.K., (2001) "Seismic Repair of Hybrid RCS BeamColumn Connections.” ACI Structural Journal. 98 (5) September-October. p.762.

Paz,M., (1994). International Handbook of Earthquake Engineering. Chapman \& Hall. New York.

Sabnis,G.M., Shroff,A.C., Kahn,L.F., (1996) Seismic Rehabilitation of Concrete Structures. ACI. Michigan.

San Francisco Cronicle, (n.d.).

http://www.sfgate.com/chronicle/special/quakes/images/ (7.2002)

Seismo-watch, (n.d.).

http://www.seismo-watch.com/EQS/AB/99/990920.Taiwan7.6html (7.2002)

Şengezer,B., (1999) 'İstanbul Metropoliten Alanında Deprem Öncesi Planlama Stratejileri.” İstanbul. No:31. s.55.

USGS, (N.D.). http://quake.wr.usg.gov/prepare/factsheets/SaferStructures/ (7.2002)

Warner,J., (1996) "Shortcrete in Seismic Repair and Retrofit." in Seismic Rehabilitation of Concrete Structures. (Ed: Sabnis,G.M., Shroff,A.C., Kahn,L.F.) ACI, Michigan. 